\title{
PYOCIN-SENSITIVITY TESTING AS A METHOD OF TYPING PSEUDOMONAS AERUGINOSA: USE OF "PHAGE-FREE" PREPARATIONS OF PYOCIN
}

\author{
Anita Rampling*, J. L. Whitby* and P. Wildy $\dagger$ \\ * Department of Bacteriology, Queen Elizabeth Hospital, Birmingham, and \\ $\dagger$ Department of Virology, University of Birmingham, Birmingham B15 2TH
}

\section{Plate XLVI}

PSEUdOMONAS cross-infection is an important problem in hospitals and therefore it is essential that there should be an efficient method for recognising epidemic strains. Numerous methods based on serology, bacteriophage sensitivity, and pyocin production or sensitivity have been proposed (Habs, 1957; Darrell and Wahba, 1964; Lindberg et al., 1964; Osman, 1965; Sutter, Hurst and Fennell, 1965; Gillies and Govan, 1966; Lányi, 1967, 1970) but no individual method is ideal.

Some methods suffer from the disadvantage of poor discrimination. For example $\mathrm{O}$-antigen typing gives defined, reliable grouping but at most 13 major groups and 15 subgroups can be recognised (Lányi, 1967). Phage typing and pyocin typing give better discrimination but less-than-complete reproducibility (Sutter and Hurst, 1966; Bergan, 1968). Discrimination has been improved by the use of combined typing methods such as serology plus pyocin typing (Wahba, 1965), serology plus phage typing (Meitert and Meitert, 1966) or pyocin production plus pyocin sensitivity (Farmer and Herman, 1969; Tagg and Mushin, 1973).

The less-than-complete reproducibility of the active pyocin production method of typing may be due to difficulty in obtaining optimal pyocin production by the test strain. We thought that the difficulty might be overcome by a modification of the original pyocin-sensitivity typing method described by Osman (1965), in which pyocin reagents are titrated and standardised before use and contaminating bacteriophage inactivated by treatment with ultraviolet light (Rampling and Whitby, 1972).

This paper compares pyocin-sensitivity typing results for 227 strains of Pseudomonas aeruginosa with those obtained by a combined phage and serotyping method (Shooter et al., 1969), and by active pyocin typing (Gillies and Govan, 1966) for 105 of the strains.

\section{MATERIALS AND METHODS}

Sources of strains of $P$. aeruginosa

Indicator strains. A set of 22 indicator strains was used for testing pyocin and bacteriophage production in the initial search for suitable pyocin-producing strains. Thirteen of 
these strains, G1-G8 and G1A-G1E, were donated by Dr R. R. Gillies, Edinburgh, and were the indicator strains used in the active pyocin-typing method. Three strains, N1H-18, N1H-26 and N1H-D, were donated by Dr A. W. Jackson, Canadian Communicable Disease Centre, Ottawa, and six strains, QE-A to QE-F, were isolated at the Queen Elizabeth Hospital, Birmingham.

Producer strains. Forty-eight strains, including the 22 indicator strains, were tested for pyocin production. Other strains tested were those donated by Dr M. T. Parker, Central Public Health Laboratory, Colindale (prefix " COL"); strains PAO-1, PAT-2, and PTS-271 donated by Professor B. Holloway, Monash University, Australia; strain PAC-1 donated by Dr Patricia Clarke, London, U.K.; pyocin production strains originally used by Dr M. A. M. Osman (Osman, 1965) (prefix "O "); strains from the National Collection of Type Cultures (prefix " NCTC"); and strains QE-G and QE-H, isolated at the Queen Elizabeth Hospital, Birmingham.

The method of selection of the typing reagents has been described in detail elsewhere (Rampling, 1973).

Strains were initially selected for their ability to produce high concentrations of pyocin and for their patterns of activity against the 22 indicator strains. Thus a preliminary set of 25 lysates was chosen and used to type 74 strains of $\boldsymbol{P}$. aeruginosa of known serotype and phage type. The results were analysed by computer by Dr Adrian Gibbs of the Australian National University, Canberra.

The 17 pyocin-producing strains then chosen were those that produced lysates most useful for discriminating between the 74 test strains. Many of the lysates contained a mixture of two or more different pyocins and the activity of some lysates was modified by addition of pyocin-neutralising serum which neutralised some but not all of the pyocins in the mixture.

Studies on $P$. aeruginosa strain PAO-1 have shown that it produces two different pyocins (Ito, Kageyama and Egami, 1970). The first, pyocin $R_{2}$, has a large molecule (c. $1 \times 10^{7}$ daltons), is resistant to the action of trypsin and can be visualised under the electron microscope, having a structure resembling the tail of a T-even coliphage. The second, pyocin $\mathrm{S}$, has a molecular weight of $c .1 \times 10^{5}$ daltons and is sensitive to the action of trypsin. We have used this classification in the analysis of our lysates (table I). The "S-type" pyocins are small-molecule, trypsin-sensitive pyocins while the " R-type" pyocins are trypsin-resistant, structurally similar to pyocin $\mathbf{R}_{2}$, and share antigens with pyocin $\mathbf{R}_{2}$. The pyocins listed as "others" are trypsin resistant and do not share antigens with pyocin $\mathbf{R}_{2}$.

Control strains for pyocin-typing experiments. Twenty-four control strains were typed routinely with each typing experiment. These strains included the original 22 indicator strains and strains PAC-1 and PAT-2. The use of a standard set of control strains served as a guide to reproducibility of results and it was therefore not necessary to titrate the pyocin reagents before each typing experiment.

Strains used to assess the typing method. The pyocin-sensitivity method was tested on 227 isolates of $P$. aeruginosa obtained from a total of 34 different foci of infection in 16 different hospitals in the British Isles. The results were compared with those obtained by other standard typing methods; all 227 isolates were typed by the serological plus phage-typing method and 105 of these, derived from 16 different foci of infection, were typed by the pyocin-production method. The isolates were donated by the Central Public Health Laboratory, Colindale; Bacteriology Department, Edinburgh University; MRC Burns Unit, Birmingham; St Thomas' Hospital, London; and Queen Elizabeth Hospital, Birmingham.

\section{Preparation of pyocin lysates}

Stock lysates. Pyocin production was induced with mitomycin $\mathrm{C}$, by a modification of the method described by Kageyama (1964). The producer strain was cultured for 16-18 h at $32^{\circ} \mathrm{C}$ in $5 \mathrm{ml}$ of Tryptone Soya Broth (TSB; Oxoid) in a 250-ml conical flask. Seventy $\mathrm{ml}$ of TSB and $125 \mu \mathrm{g}$ of mitomycin C (Sigma Chemical Company) were then added to the culture and incubation was continued for a further $6 \mathrm{~h}$ in a shaking waterbath at $32^{\circ} \mathrm{C}$. The lysate 
was shaken briefly with a few drops of chloroform to kill the unlysed bacterial cells and then clarified by centrifugation. The clear supernatant fluid contained the pyocins. Pyocin concentration in these " stock" lystates was tested by titration on appropriate indicators and the lysates were stored up to 6 months at $4^{\circ} \mathrm{C}$.

Preparation of typing reagents from stock lysates. The method used for inactivation of bacteriophage was a slight modification of that described by Rampling and Whitby (1972). One-ml amounts of lysate were spread on 6-cm glass petri dishes to give thin layers $c .0 .33 \mathrm{~mm}$ in depth. The samples were then exposed to the emission from a "Chromatolite" $30-\mathrm{W}$ low-pressure mercury discharge lamp (Engelhard Hanovia Ltd) for $10 \mathrm{~min}$. at $10 \mathrm{~cm}$ from the source, and agitated throughout treatment. Four samples were treated at a time.

Most of the pyocin preparations were then diluted 1 in 10 in nutrient broth containing $0.2 \mathrm{mg}$ per litre of N-butylparahydroxybenzoate (Koch-Light Laboratories, Ltd), an antimycotic. A few of the lysates were modified by the addition of heterologous antipyocin serum, which neutralised some of the pyocins in the lysates. Serum-treated lysates were diluted 1 in 5 with nutrient broth containing the antimycotic. The diluted typing reagents remained reasonably stable for 4 weeks at $4^{\circ} \mathrm{C}$.

\section{TABLE I}

Reagents for pyocin-sensitivity typing

\begin{tabular}{|c|c|c|c|c|c|}
\hline \multirow{2}{*}{$\begin{array}{l}\text { Reagent } \\
\text { number }\end{array}$} & \multirow{2}{*}{$\begin{array}{l}\text { Producer } \\
\text { strain of } \\
\text { Pseudomonas } \\
\text { aeruginosa }\end{array}$} & \multirow{2}{*}{$\begin{array}{l}\text { Treatment after } \\
\text { ultraviolet } \\
\text { irradiation at } \\
35,000 \text { ergs per } \mathrm{mm}^{2}\end{array}$} & \multicolumn{3}{|c|}{$\begin{array}{l}\text { Most sensitive } \\
\text { indicators for pyocins of type }\end{array}$} \\
\hline & & & $\mathbf{R}$ & $\mathrm{S}$ & other \\
\hline 1 & G4 & \multirow{24}{*}{$\begin{array}{l}\text { Dilute* } 1 \text { in } 10 \\
\text { Dilute } 1 \text { in } 10 \\
\text { Dilute } 1 \text { in } 10 \\
\text { Dilute } 1 \text { in } 10 \\
\text { Dilute } 1 \text { in } 10 \\
\text { Dilute } 1 \text { in } 10 \\
\text { Dilute } 1 \text { in } 10 \\
\text { Dilute } 1 \text { in } 10 \\
\text { Dilute } 1 \text { in } 10 \\
\text { Dilute } 1 \text { in } 10 \\
\text { Dilute } 1 \text { in } 10 \\
\text { Dilute } 1 \text { in } 10 \\
\text { Add antiserum } 1 \uparrow \text {, } \\
\text { dilute } 1 \text { in } 5 \\
\text { Add antiserum } 1 \text {, } \\
\text { dilute } 1 \text { in } 5 \\
\text { Dilute } 1 \text { in } 10 \\
\text { Dilute } 1 \text { in } 10 \\
\text { Add antiserum } 1 \text {, } \\
\text { dilute } 1 \text { in } 5 \\
\text { Dilute } 1 \text { in } 10 \\
\text { Add antiserum } 1 \text {, } \\
\text { dilute } 1 \text { in } 5 \\
\text { Dilute } 1 \text { in } 10 \\
\text { Dilute } 1 \text { in } 10 \\
\text { Add antiserum } 1, \\
\text { dilute } 1 \text { in } 5 \\
\text { Add antisera } 1 \\
\text { and } 2 \ddagger \text { dilute } 1 \text { in } 5 \\
\text { Dilute } 1 \text { in } 10 \\
\quad \ldots\end{array}$} & $G_{1}$ & & \\
\hline$\frac{1}{2}$ & PAC -1 & & G1 & $\cdots$ & $\cdots$ \\
\hline 3 & PAT-2 & & G1 & $\ldots$ & \\
\hline 4 & QE-E & & G1 & $\cdots$ & G1 $\dddot{E}$ \\
\hline 5 & $\mathrm{QE}-\bar{G}$ & & G8 & G1A & N1H-26 \\
\hline 6 & G1A & & G1 & G1E & \\
\hline 7 & G1C & & G1 & $\ldots$ & \\
\hline 8 & $0-39$ & & G8 & $\ldots$ & G1C \\
\hline 9 & PAC-1 & & $\ldots$ & & $\mathrm{G} 4$ \\
\hline 10 & NCTC -6750 & & $\ldots$ & G7 & G3 \\
\hline 11 & G1 & & $\ldots$ & & G7 \\
\hline 12 & COL-4110 & & $\ldots$ & QE-B & G1 \\
\hline 13 & $\mathrm{~N} 1 \mathrm{H}-26$ & & $\ldots$ & N1H-18 & -1 \\
\hline 14 & QE-E & & $\cdots$ & $\ldots$ & G1E \\
\hline 15 & QE-D & & G1 & & G1E \\
\hline $\begin{array}{l}16 \\
17\end{array}$ & $\begin{array}{l}\text { G1D } \\
\text { G1A }\end{array}$ & & $\begin{array}{l}\text { G1 } \\
\ldots\end{array}$ & $\begin{array}{l}\text { N1H-18 } \\
\text { G1E }\end{array}$ & $\ldots$ \\
\hline & & & & & G1F \\
\hline $\begin{array}{l}18 \\
19\end{array}$ & $\begin{array}{l}\text { QE-F } \\
\text { QE-A }\end{array}$ & & $\cdots$ & $\mathrm{G} 3{ }^{\circ}$ & \\
\hline 20 & PTS-271 & & & $\cdots$ & G8 \\
\hline $\begin{array}{l}21 \\
22\end{array}$ & $\begin{array}{l}\text { N1H-18 } \\
\text { N1H-D }\end{array}$ & & $\begin{array}{l}\text { G1 } \\
\ldots\end{array}$ & G1 $\dddot{A}$ & $\mathrm{~N} 1 \dddot{\mathrm{H}}-26$ \\
\hline 23 & N1H-D & & & G1A & \\
\hline & & & $\cdots$ & & $\cdots$ \\
\hline 24 & NCTC-10332 & & G1 & G1B & $\ldots$ \\
\hline $25 \S$ & $\cdots$ & & $\cdots$ & $\cdots$ & $\cdots$ \\
\hline
\end{tabular}

* In nutrient broth plus antimycotic (see text).

$\uparrow$ Prepared against lystate of strain G4.

$\ddagger$ Prepared against lysate of strain PAC-1.

$\S$ Control: diluting broth plus antimycotic plus antisera 1 and 2. 


\section{Preparation of neutralising antisera to lysates of strains G4 and PAC-1}

Antisera to the crude pyocin-containing lysates were prepared in rabbits. Equal volumes of lysate and Freund's complete adjuvant (Freund, Casals-Ariet and Genghof, 1940) were mixed until a stable emulsion was obtained. Two $\mathrm{ml}$ of the emulsion was injected into the hind-leg muscle of a rabbit and, after an interval of 4 weeks, $2 \mathrm{ml}$ of the mixture was injected into the other leg. The animal was bled after one more week.

\section{Typing by the pyocin-sensitivity method}

Preparation of plates. One drop of overnight broth culture of the test strain was mixed with $5 \mathrm{ml}$ of molten cool 0.7\% agar (Oxoid Agar no. 1, L11). This was overlayered to a depth of $1 \mathrm{~mm}$ on nutrient-agar plates, which were then dried. The pyocin reagents were applied with a multiloop phage applicator (Biddulph and Co., Manchester, Ltd). The plates were then dried in air and incubated for $16-18 \mathrm{~h}$ at $27^{\circ} \mathrm{C}$.

Reading and recording of results. Initially it was thought that distinction between sensitivity to the S-type pyocins, which gave large hazy zones of inhibition, and to the largemolecule pyocins, which gave clear-cut zones (fig.) might be of value in distinguishing between strains. However, experience showed that it was not always possible to distinguish between the zones produced by the two different types of pyocin. Results are therefore recorded as " 2 " for strong zones of inhibition and " 1 " for weak zones of inhibiton.

Reproducibility of pyocin-sensitivity pattern. Six of the control strains were each typed eight times in one experiment. For each strain this enabled 28 comparisons of each test to be made with each of the others. Any inhibiton reaction, whether " 1 " or " 2 ", was regarded as positive and the numbers of discrepant pyocin reactions were then noted for each comparison.

\section{Combined serological and phage typing}

Combined serological and phage typing had been performed on all the isolates at the Central Public Health Laboratory, Colindale. The method of phage typing is described by Shooter et al. (1966) and the method of serotyping is described by Shooter et al. (1969). Cultures of different serotypes were regarded as distinct regardless of any similarity in phagetyping patterns. Subdivision of strains was first based on serological differences, and isolates of the same serotype were then regarded as distinguishable if there were differences of three or more strong phage reactions at routine test dilution (Martin, 1971).

\section{Active pyocin typing}

One hundred and five of the isolates of $P$. aeruginosa were typed by the active pyocintyping method (Gillies and Govan, 1966). Seventy-four of them had been typed in Edinburgh by $\mathrm{Dr}$ Govan and 31 by the same method at St Thomas' Hospital, London. Two strains were regarded as distinguishable if there was a difference of one or more inhibitions of the indicator strains.

Govan and Gillies (1969) modified their method by using five additional indicator strains to subtype the most commonly occurring pyocin type 1 . Some of the isolates that we obtained from Edinburgh had been typed before this modification had been introduced but those from St Thomas' Hospital, London, had all been typed by the modified method.

\section{RESULTS}

Table I gives the details of the set of 24 typing reagents that was finally selected for the pyocin-sensitivity method.

Table II gives the numbers of discrepant pyocin reactions noted when six of 
the control strains were tested for reproducibility of typing patterns. Some strains (G1 and QE-E) gave completely consistent results while others did not. Inspection of the crude data (not shown in the table) indicated that this was referable to particular pyocin preparations. However, taking all the results together, it is clear that on only three occasions out of 168 comparisons $(1.7 \%)$ did any strain give more than two discrepancies.

In our subsequent reading of the typing results we have regarded any inhibition reaction (whether graded 1 or 2 ) as positive and any two strains with three or more differences in their pyocin-sensitivity patterns as distinct. Strains with only one or two differences in typing pattern are regarded as indistinguishable.

Table III shows examples of the types of pattern that we obtained using the pyocin-sensitivity method.

Table IV is an analysis of the typing results for 74 of the 105 isolates that were also typed by pyocin production and the serological plus phage-typing method, including those shown in detail in table III. Coding letters indicate how many different strains were distinguished in each group by each typing method. When strain codings are compared for each of the different methods in turn the percentage agreement between the methods can be calculated. Examination of all 105 isolates typed by all three methods showed that there was $73.3 \%$ agreement between pyocin-sensitivity and pyocin-production methods; $71.4 \%$ agreement between pyocin-production and serological plus phage typing; and $83.8 \%$ agreement between pyocin-sensitivity and serological plus phage typing.

The most frequent cause of lack of agreement between pyocin-sensitivity and serological plus phage typing was the presence of non-typable (NT) strains (table V). There was a slightly higher percentage of NT strains by the

TABLE II

Number of discrepancies in pyocin-sensitivity reaction when six cultures of $P$. aeruginosa were typed eight times in one experiment*

\begin{tabular}{l|rrrr}
$\begin{array}{c}\text { Designation of } \\
\text { culture }\end{array}$ & \multicolumn{4}{c}{$\begin{array}{c}\text { Number of tests in which the } \\
\text { number of differences between } \\
\text { pyocin-sensitivity patterns was }\end{array}$} \\
\hline & 0 & 1 & 2 & 3 \\
\hline G1 & 28 & 0 & 0 & 0 \\
QE-E & 28 & 0 & 0 & 0 \\
G1-B & 8 & 16 & 4 & 0 \\
QE-A & 5 & 13 & 8 & 2 \\
QE-B & 21 & 7 & 0 & 0 \\
G6 & 7 & 14 & 6 & 1 \\
\hline All strains & 97 & 50 & 18 & 3 \\
\hline
\end{tabular}

* Each sensitivity pattern was compared separately with each of the other sensitivity patterns for the same culture ( 28 comparisons per culture). 
TABLE III

Pyocin-sensitivity patterns for isolates of $P$. aeruginosa from two different foci of infection

\begin{tabular}{|c|c|c|c|c|c|c|c|c|c|c|c|c|c|c|c|c|c|c|c|c|c|c|c|c|c|}
\hline \multirow{2}{*}{$\begin{array}{c}\text { Serial } \\
\text { number } \\
\text { of } \\
\text { isolate }\end{array}$} & \multicolumn{24}{|c|}{ Degree of sensitivity to pyocin number } & \multirow{2}{*}{$\underset{\text { coding }}{\text { Strain }}$} \\
\hline & 1 & 2 & 3 & 4 & 5 & 6 & 7 & 8 & 9 & 10 & 11 & 12 & 13 & 14 & 15 & 16 & 17 & 18 & 19 & 20 & 21 & 22 & 23 & 24 & \\
\hline $\begin{array}{c}\text { Focus } I \\
128 \\
125 \\
226 \\
229 \\
230 \\
235 \\
236\end{array}$ & $\begin{array}{l}\ldots \\
2 \\
2 \\
2 \\
\ldots \\
\ldots\end{array}$ & $\begin{array}{c}2 \\
\dddot{2} \\
2 \\
1 \\
2 \\
2\end{array}$ & $\begin{array}{l}2 \\
\dddot{2} \\
2 \\
1 \\
1 \\
2\end{array}$ & $\begin{array}{c}2 \\
\dddot{2} \\
2 \\
2 \\
2 \\
2\end{array}$ & $\begin{array}{l}2 \\
2 \\
2 \\
2 \\
2 \\
2 \\
2\end{array}$ & $\begin{array}{l}\mathbf{2} \\
\mathbf{2} \\
\mathbf{2} \\
\mathbf{2} \\
2 \\
2 \\
2\end{array}$ & $\begin{array}{l}2 \\
2 \\
2 \\
2 \\
2 \\
2 \\
2\end{array}$ & $\begin{array}{l}2 \\
2 \\
2 \\
2 \\
2 \\
2 \\
2\end{array}$ & $\begin{array}{l}2 \\
\ldots \\
\ldots \\
\ldots \\
\dddot{2} \\
2\end{array}$ & $\begin{array}{c}\ldots \\
\dddot{2} \\
2 \\
2 \\
\ldots \\
\ldots\end{array}$ & $\begin{array}{c}2 \\
\dddot{2} \\
2 \\
2 \\
2 \\
2\end{array}$ & $\begin{array}{l}1 \\
1 \\
2 \\
2 \\
2 \\
1 \\
1\end{array}$ & $\begin{array}{l}\ldots \\
\ldots \\
\ldots \\
\ldots \\
\ldots \\
\ldots\end{array}$ & $\begin{array}{l}\ldots \\
\ldots \\
\ldots \\
\dddot{2} \\
2\end{array}$ & $\begin{array}{c}2 \\
\dddot{2} \\
2 \\
2 \\
2 \\
2\end{array}$ & $\begin{array}{l}\ldots \\
\dddot{2} \\
2 \\
2 \\
\cdots \\
\cdots\end{array}$ & $\begin{array}{l}\ldots \\
\ldots \\
\ldots \\
\ldots \\
\ldots \\
\ldots \\
\ldots\end{array}$ & $\begin{array}{c}1 \\
\ldots \\
\ldots \\
\ldots \\
\dddot{2} \\
2\end{array}$ & $\begin{array}{l}\ldots \\
\ldots \\
\ldots \\
\cdots \\
\cdots \\
\ldots\end{array}$ & $\begin{array}{l}\ldots \\
\ldots \\
\ldots \\
\ldots \\
\ldots \\
\ldots\end{array}$ & $\begin{array}{l}2 \\
1 \\
2 \\
2 \\
2 \\
2 \\
2\end{array}$ & $\begin{array}{l}\dddot{2} \\
1 \\
1 \\
1 \\
\ldots\end{array}$ & $\begin{array}{c}\dddot{1} \\
1 \\
1 \\
1 \\
\cdots \\
\cdots\end{array}$ & $\begin{array}{l}\ldots \\
\dddot{2} \\
2 \\
2 \\
\ldots \\
\ldots\end{array}$ & $\begin{array}{l}\mathbf{A} \\
\mathbf{B} \\
\mathbf{C} \\
\mathbf{C} \\
\mathbf{C} \\
\mathbf{A} \\
\mathbf{A}\end{array}$ \\
\hline $\begin{array}{c}\text { Focus II } \\
1504 \\
1514 \\
1549 \\
1550 \\
1555 \\
1595 \\
1635 \\
1656\end{array}$ & $\begin{array}{c}2 \\
2 \\
2 \\
2 \\
2 \\
2 \\
\ldots \\
\cdots\end{array}$ & $\begin{array}{c}2 \\
2 \\
2 \\
2 \\
2 \\
2 \\
2 \\
\cdots \\
\ldots\end{array}$ & $\begin{array}{c}2 \\
2 \\
2 \\
2 \\
2 \\
2 \\
\ldots \\
\ldots\end{array}$ & $\begin{array}{c}2 \\
2 \\
2 \\
2 \\
2 \\
2 \\
\ldots \\
\ldots\end{array}$ & $\begin{array}{c}2 \\
2 \\
2 \\
2 \\
2 \\
2 \\
\dddot{2}\end{array}$ & $\begin{array}{c}2 \\
2 \\
2 \\
2 \\
2 \\
2 \\
\ldots \\
\ldots\end{array}$ & $\begin{array}{c}2 \\
2 \\
2 \\
2 \\
2 \\
2 \\
\ldots \\
\ldots\end{array}$ & $\begin{array}{c}2 \\
2 \\
2 \\
2 \\
2 \\
2 \\
2 \\
\ldots \\
\ldots\end{array}$ & $\begin{array}{l}\ldots \\
\ldots \\
\ldots \\
\ldots \\
\ldots \\
\ldots \\
\ldots\end{array}$ & $\begin{array}{c}1 \\
\ldots \\
1 \\
1 \\
1 \\
1 \\
\ldots \\
\ldots\end{array}$ & $\begin{array}{l}\ldots \\
\ldots \\
\ldots \\
\ldots \\
\ldots \\
2\end{array}$ & $\begin{array}{l}\ldots \\
\ldots \\
\ldots \\
\ldots \\
\ldots \\
\ldots \\
1\end{array}$ & $\begin{array}{l}\ldots \\
\ldots \\
\ldots \\
\ldots \\
\ldots \\
1\end{array}$ & $\begin{array}{l}\ldots \\
\ldots \\
\ldots \\
\ldots \\
\ldots \\
\ldots \\
\ldots\end{array}$ & $\begin{array}{c}2 \\
2 \\
2 \\
2 \\
2 \\
2 \\
\ldots \\
\ldots\end{array}$ & $\begin{array}{c}2 \\
2 \\
2 \\
2 \\
2 \\
2 \\
\ldots \\
\ldots\end{array}$ & $\begin{array}{l}\ldots \\
\ldots \\
\ldots \\
\ldots \\
\ldots \\
\ldots \\
\ldots\end{array}$ & $\begin{array}{c}2 \\
2 \\
2 \\
2 \\
2 \\
2 \\
\ldots \\
\ldots\end{array}$ & $\begin{array}{c}\ldots \\
\dddot{1} \\
1 \\
1 \\
\ldots \\
\ldots\end{array}$ & $\begin{array}{l}\ldots \\
\ldots \\
\ldots \\
\ldots \\
\ldots \\
\ldots \\
\ldots\end{array}$ & $\begin{array}{c}2 \\
2 \\
2 \\
2 \\
2 \\
2 \\
\ldots \\
\ldots\end{array}$ & $\begin{array}{l}\ldots \\
\ldots \\
\ldots \\
\ldots \\
\ldots \\
\ldots \\
2\end{array}$ & $\begin{array}{l}\ldots \\
\ldots \\
\ldots \\
\cdots \\
\cdots \\
\dddot{i}\end{array}$ & $\begin{array}{c}2 \\
2 \\
2 \\
2 \\
2 \\
2 \\
\ldots \\
\ldots\end{array}$ & $\begin{array}{l}\mathbf{A} \\
\mathbf{A} \\
\mathbf{A} \\
\mathbf{A} \\
\mathbf{A} \\
\mathbf{A} \\
\mathbf{N} \mathbf{B}\end{array}$ \\
\hline
\end{tabular}

2 = Strong reaction. $\quad 1=$ Weak reaction. $\quad \mathrm{NT}=$ Not typable.

*Within each group of results, isolates judged to be indistinguishable were allocated the same coding letter.

combined method, because a few strains were classified as NT if they did not serotype and gave only one or two reactions at $1000 \times$ the routine test dilution of phage. Non-typable strains accounted for $9.7 \%$ of the total of $15.0 \%$ discrepancies observed in typing 227 strains by these two methods.

Non-typable strains accounted for $12.4 \%$ of the total of $28.6 \%$ of disagreements between pyocin-production and serological plus phage typing and for $5.7 \%$ of the total of $26.7 \%$ of disagreements between pyocin-production and pyocin-sensitivity.

Many of the discrepancies between the pyocin-production method and the other two methods were due to subdivision of the pyocin-production types by one or both of the other two methods or vice versa. The actual number of different strains distinguished within each small focus of infection was similar for all three methods (table VI). However, when the whole group of 105 isolates was examined, 26 different types could be distinguished by pyocin production, 35 by serology plus phage sensitivity and 40 by pyocin sensitivity.

Our results showed that pyocin-sensitivity typing correlated rather better with combined serological plus phage typing than with the pyocin-production method. However, the reason for this is that most of the isolates that were pyocin typed in Edinburgh (table IV) were typed before the method was improved to give greater discrimination between type 1 strains (Govan and Gillies, 1969). Examination of the 31 isolates that were typed at St Thomas' Hospital by the improved method, showed that there was very good correlation between all three typing techniques. For this group of isolates there was $93.5 \%$ agreement between pyocin production and pyocin sensitivity, and between pyocin sensitivity and serology plus phage typing, and there was $90.3 \%$ agreement between pyocin production and serological plus phage typing. 
PYOCIN-SENSITIVITY TYPING OF P. AERUGINOSA

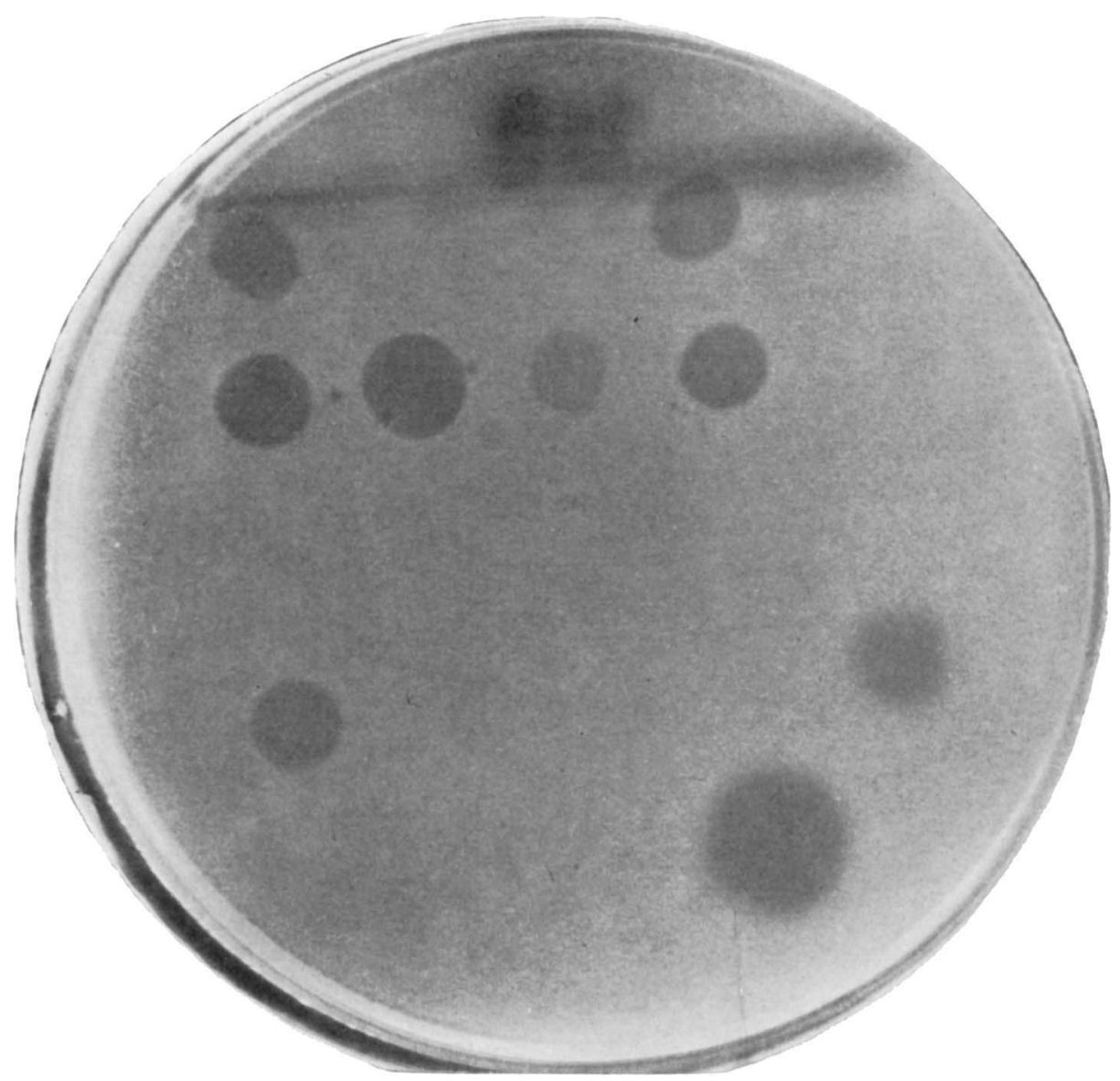

FIGURE.-An example of pyocin-sensitivity testing showing clear-cut and hazy zones. The large zone at bottom right is an example of the spreading hazy zone of inhibition produced by smallmolecule "S-type" pyocin. 
TABLE IV

Comparison of typing results for 74 isolates of $P$. aeruginosa from 11 different foci of infection

\begin{tabular}{|c|c|c|c|c|}
\hline \multirow[b]{2}{*}{$\begin{array}{c}\text { Focus of } \\
\text { infection } \\
\text { no. }\end{array}$} & \multicolumn{3}{|c|}{ Strain coding* by } & \multirow[b]{2}{*}{$\begin{array}{l}\text { Number of } \\
\text { isolates }\end{array}$} \\
\hline & $\begin{array}{c}\text { Pyocin- } \\
\text { sensitivity } \\
\text { typing }\end{array}$ & $\begin{array}{c}\text { Gillies' pyocin- } \\
\text { production } \\
\text { typing }\end{array}$ & $\begin{array}{l}\text { Serological } \\
\text { plus phage } \\
\text { typing }\end{array}$ & \\
\hline I & $\begin{array}{l}\text { A } \\
\text { B } \\
\mathbf{C} \\
\text { C } \\
\text { A }\end{array}$ & $\begin{array}{l}\text { A } \\
\text { B } \\
\text { A } \\
\text { NT } \\
\text { C }\end{array}$ & $\begin{array}{l}\text { A } \\
\text { B } \\
\mathbf{C} \\
\text { C } \\
\text { A }\end{array}$ & $\begin{array}{l}2 \\
1 \\
2 \\
1 \\
1\end{array}$ \\
\hline II & $\begin{array}{l}\text { A } \\
\text { A } \\
\text { NT } \\
\text { B }\end{array}$ & $\begin{array}{l}\text { A } \\
\text { B } \\
\text { C } \\
\text { D }\end{array}$ & $\begin{array}{l}\text { A } \\
\text { A } \\
\text { NT } \\
\text { B }\end{array}$ & $\begin{array}{l}5 \\
1 \\
1 \\
1\end{array}$ \\
\hline III & $\begin{array}{l}\mathbf{A} \\
\mathbf{A} \\
\mathbf{A}\end{array}$ & $\begin{array}{l}\mathbf{A} \\
\mathbf{B} \\
\mathbf{C}\end{array}$ & $\begin{array}{l}\mathrm{A} \\
\mathrm{A} \\
\mathrm{A}\end{array}$ & $\begin{array}{l}4 \\
1 \\
3\end{array}$ \\
\hline IV & $\begin{array}{l}\mathbf{A} \\
\mathbf{B} \\
\mathbf{C}\end{array}$ & $\begin{array}{l}\text { A } \\
\text { B } \\
\text { B }\end{array}$ & $\begin{array}{l}\mathrm{A} \\
\mathrm{B} \\
\mathbf{C}\end{array}$ & $\begin{array}{l}3 \\
2 \\
2\end{array}$ \\
\hline V & $\begin{array}{l}\text { A } \\
\text { B } \\
\text { C } \\
\text { D } \\
\text { D } \\
\text { NT }\end{array}$ & $\begin{array}{l}\text { A } \\
\text { NT } \\
\text { A } \\
\text { A } \\
\text { A } \\
\text { NT }\end{array}$ & $\begin{array}{l}\text { A } \\
\text { B } \\
\text { C } \\
\text { B } \\
\text { D } \\
\text { NT }\end{array}$ & $\begin{array}{l}1 \\
1 \\
1 \\
2 \\
2 \\
1\end{array}$ \\
\hline VI & $\begin{array}{l}\text { A } \\
\text { B } \\
\text { C } \\
\text { D }\end{array}$ & $\begin{array}{l}\text { A } \\
\text { B } \\
\text { C } \\
\text { D }\end{array}$ & $\begin{array}{l}\text { A } \\
\text { B } \\
\text { NT } \\
\text { C }\end{array}$ & $\begin{array}{l}3 \\
1 \\
1 \\
1\end{array}$ \\
\hline VII & $\begin{array}{l}\mathrm{A} \\
\mathrm{B}\end{array}$ & $\begin{array}{l}\text { A } \\
\text { B }\end{array}$ & $\begin{array}{l}\mathrm{A} \\
\mathrm{B}\end{array}$ & $\begin{array}{l}4 \\
1\end{array}$ \\
\hline VIII & $\begin{array}{l}\mathbf{A} \\
\mathbf{A} \\
\mathbf{A} \\
\mathbf{B}\end{array}$ & $\begin{array}{l}\text { A } \\
\text { B } \\
\text { B } \\
\mathbf{C}\end{array}$ & $\begin{array}{l}\text { NT } \\
\text { NT } \\
\text { A } \\
\text { B }\end{array}$ & $\begin{array}{l}2 \\
2 \\
1 \\
1\end{array}$ \\
\hline IX & $\begin{array}{l}\text { A } \\
\text { B } \\
\text { C } \\
\text { D }\end{array}$ & $\begin{array}{l}\text { A } \\
\text { B } \\
\text { C } \\
\text { D }\end{array}$ & $\begin{array}{l}\mathbf{A} \\
\mathbf{B} \\
\mathbf{B} \\
\mathbf{C}\end{array}$ & $\begin{array}{l}3 \\
1 \\
1 \\
1\end{array}$ \\
\hline$x$ & $\begin{array}{l}\text { A } \\
\mathbf{B} \\
\mathbf{C} \\
\mathbf{A} \\
\mathbf{D}\end{array}$ & $\begin{array}{l}\text { A } \\
\text { B } \\
\text { A } \\
\text { C } \\
\text { D }\end{array}$ & $\begin{array}{l}\text { A } \\
\text { B } \\
\text { A } \\
\text { C } \\
\text { D }\end{array}$ & $\begin{array}{l}2 \\
1 \\
1 \\
2 \\
1\end{array}$ \\
\hline XI & $\begin{array}{l}\text { A } \\
\text { B } \\
\text { C } \\
\text { D }\end{array}$ & $\begin{array}{l}\text { A } \\
\text { B } \\
\text { C } \\
\text { D }\end{array}$ & $\begin{array}{l}\text { A } \\
\text { B } \\
\text { NT } \\
\text { NT }\end{array}$ & $\begin{array}{l}1 \\
3 \\
1 \\
1\end{array}$ \\
\hline
\end{tabular}

* For each focus of infection and each typing method strains judged to be indistinguishable were allocated the same coding, A-D.

NT $=$ not typable. 
TABLE V

Proportion of strains of $P$. aeruginosa non-typable by four typing methods

\begin{tabular}{l|cc}
\hline \multicolumn{1}{c|}{ Typing method } & $\begin{array}{c}\text { Number of } \\
\text { isolates examined }\end{array}$ & $\begin{array}{c}\text { Proportion } \\
\text { non-typable } \\
(\%)\end{array}$ \\
\hline Serology & 227 & $11 \cdot 4$ \\
Phage sensitivity & 227 & $3 \cdot 1$ \\
Pyocin production & 105 & $2 \cdot 9$ \\
Pyocin sensitivity & 227 & 1.8 \\
\hline
\end{tabular}

TABLE VI

Numbers of different strains distinguished within each focus of infection by three typing methods

\begin{tabular}{|c|c|c|c|c|}
\hline \multirow{2}{*}{$\begin{array}{c}\text { Focus of } \\
\text { infection } \\
\text { no. }\end{array}$} & \multirow{2}{*}{$\begin{array}{c}\text { Number } \\
\text { of } \\
\text { isolates } \\
\text { typed }\end{array}$} & \multicolumn{3}{|c|}{ Number of types distinguished by } \\
\hline & & $\begin{array}{c}\text { pyocin } \\
\text { sensitivity }\end{array}$ & $\begin{array}{c}\text { Pyocin } \\
\text { production }\end{array}$ & $\begin{array}{l}\text { Serology } \\
\text { plus phage }\end{array}$ \\
\hline $\begin{array}{l}\text { I } \\
\text { II } \\
\text { III } \\
\text { IV } \\
\text { V } \\
\text { VI } \\
\text { VII } \\
\text { VIII } \\
\text { IX } \\
\text { X } \\
\text { XI }\end{array}$ & $\begin{array}{l}7 \\
8 \\
8 \\
7 \\
8 \\
6 \\
5 \\
6 \\
6 \\
7 \\
6\end{array}$ & $\begin{array}{l}3 \\
2 \\
1 \\
3 \\
4 \\
4 \\
2 \\
2 \\
4 \\
4 \\
4\end{array}$ & $\begin{array}{l}3 \\
4 \\
3 \\
2 \\
1 \\
4 \\
2 \\
3 \\
4 \\
4 \\
4\end{array}$ & $\begin{array}{l}3 \\
2 \\
1 \\
3 \\
4 \\
3 \\
2 \\
2 \\
3 \\
4 \\
2\end{array}$ \\
\hline All foci & 74 & 33 & 34 & 29 \\
\hline
\end{tabular}

\section{Discussion}

Our comparative studies have shown that pyocin-sensitivity typing results correlate very closely with the results obtained by combined serological and phage typing and the pyocin-production method.

These results also confirm the value of the combined serological- and phage-typing method as a reliable and sensitive means of typing strains of $P$. aeruginosa. The O-serotype is a stable marker and subdivision of O-serogroups by phage typing is a method that will detect minor differences between strains. This method is the most suitable of the three methods that we have examined for use in a central reference laboratory as it is more reliable than any single method used alone. The major criticism of this method at present is the rather high percentage of isolates that are untypable serologically. 
The use of pyocin or phage sensitivities as epidemiological markers for $P$. aeruginosa has been criticised by some workers (Bobo et al., 1973) on the grounds that some strains tend to produce mucoid forms with altered cell surface properties, which may affect pyocin or phage receptors. However, recent work (Martin, 1973) has shown that slime production by $P$. aeruginosa grown in vitro depends on the presence of phage in the lytic cycle. Experimentally produced mucoid strains appear to be identical to naturally occurring mucoid variants and remain sensitive to the phage that has induced the colonial variation. In addition, both natural and experimentally produced mucoid strains revert rapidly to non-mucoid growth and therefore sensitivity typing of these strains should not be a problem.

The pyocin-sensitivity method has a number of features that recommend its use in a routine hospital laboratory. The use of pyocin-containing lysates, in the way we have described, is simple and results are easy to read. Multiple inoculation devices are used and only a single overnight incubation is needed. The concentrated lysates are stable for at least 6 months on storage and could easily be prepared in a central laboratory where they could be treated in bulk to inactive bacteriophage and then distributed to peripheral laboratories.

A number of workers have proposed modifications for the pyocinproduction method. Tripathy and Chadwick (1971) incorporated low concentrations of mitomycin $\mathrm{C}$ in their plates and showed that this improved pyocin production by the test strain and thus increased the reproducibility of their results. Jones et al. (1974) have developed a simple method that depends upon pyocin production by broth cultures of the test organism, which are then tested for the inhibition of 18 carefully selected indicator strains. This method gives good discrimination and reliable results but does not overcome the problem of bacteriophage contamination in the lysates.

Tagg and Mushin (1973) have already shown that pyocin-sensitivity patterns for a small set of pyocin lysates can be a useful and reliable adjunct to the pyocin-production method of Gillies and Govan. We suggest that the use of a larger collection of standardised pyocin lysates, which do not contain phage, provides a simple and efficient method for characterising strains and that this method alone is simple and satisfactory for routine typing. Further studies are now in progress with the object of improving our preparations to give better discrimination. Because our lysates contain more than one bacteriocin and there is considerable overlap in reactions, we hope to be able to find a technique for making single bacteriocin preparations. We have tried to go part of the way towards this aim by using antipyocin serum but our ultimate objective is to produce a set of single-bacteriocin-producing strains that are not lysogenic and thus to dispense with the use of serum or ultraviolet irradiation.

\section{SUMMARY}

A method for pyocin-sensitivity typing by means of " phage-free " preparations of pyocin is described. The method was tested on 227 isolates of $P$. aeruginosa, collected from 34 different foci of infection in hospitals in the 
British Isles and the results were compared with those for combined serological and phage typing of all strains and pyocin production of 105 of the isolates. It is concluded that pyocin-sensitivity typing is a simple and reliable method giving a high degree of discrimination, comparable to that of combined serological and phage typing, and it is suitable for use in routine hospital laboratories.

We are grateful to Dr M. T. Parker and the staff of the Cross-Infection Reference Laboratory, Colindale, for carrying out serology and phage typing on all of our isolates, and to Dr R. R. Gillies and Dr J. R. W. Govan of the University of Edinburgh and Professor I. Phillips of St Thomas' Hospital, London, for carrying out " active" pyocin typing on 105 of the isolates. Thanks are also due to Dr Parker for his helpful criticism and assistance in the preparation of this manuscript.

We wish to acknowledge financial support from the Endowment Research Fund Committee, Queen Elizabeth Medical Centre.

\section{REFERENCES}

Bergan, T. 1968. Typing of Pseudomonas aeruginosa by pyocine production. Acta. path. microbiol. scand., 72, 401.

Bobo, R. A., Newton, E. J., Jones, L. F., Farmer, L. H. and Farmer, J. J. III. 1973. Nursery outbreak of Pseudomonas aeruginosa: epidemiological conclusions from five different typing methods. Appl. Microbiol., 25, 414.

Darrell, J. H. AND WaHBA, A. H. 1964. Pyocin-typing of hospital strains of Pseudomonas pyocyanea. J. clin. Path., 17, 236.

FARMER, J. J. III AND HeRman, L. G. 1969. Epidemiological fingerprinting of Pseudomonas aeruginosa by the production of and sensitivity to pyocin and bacteriophage. Appl. Microbiol., 18, 760.

Freund, J., Casals-Ariet, J. AND Genghof, D. S. 1940. The synergistic effect of paraffin-oil combined with heat-killed tubercle bacilli. J. Immunol., 38, 67.

Gillies, R. R. AND Govan, J. R. W. 1966. Typing of Pseudomonas pyocyanea by pyocine production. J. Path Bact., 91, 339.

Govan, J. R. W. AND Gillies, R. R. 1969. Further studies in the pyocine typing of Pseudomonas pyocyanea. J. med. Microbiol., $2,17$.

HABS, I. 1957. Untersuchungen über die O-antigene von Pseudomonas aeruginosa. Z. Hyg. InfektKrankh., 144, 218.

Ito, S., KageYAma, M. AND Egami, F. 1970. Isolation and characterisation of pyocins from several strains of Pseudomonas aeruginosa. J. gen. appl. Microbiol., Tokyo, 16, 205.

Jones, L. F., ZakanyCZ, J. P., Thomas, E. T. AND FARMer, J. J. III. 1974. Pyocin typing of Pseudomonas aeruginosa: a simplified method. Appl. Microbiol., 27, 400.

KageYama, M. 1964. Studies of a pyocin. 1. Physical and chemical properties. J. Biochem., Tokyo, 55, 49.

LÁNYI, B. 1967. Serological properties of Pseudomonas aeruginosa. I. Group-specific somatic antigens. Acta microbiol. hung., 13, 295.

LÁNYI, B. 1970. Serological properties of Pseudomonas aeruginosa. II. Type-specific thermolabile (flagellar) antigens. Acta microbiol. hung., 17, 35.

LiNDBERG, R. B., LATTA, R. L., BRAME, R. E. AND MoNCRIEF, J. A. 1964. Definitive bacteriophage typing system for Pseudomonas aeruginosa. American Society for Microbiology. Bact. Proc., p. 81.

Martin, D. R. 1971. Variation in Pseudomonas aeruginosa. Ph.D Thesis, University of London.

MARTIN, D. R. 1973. Mucoid variation in Pseudomonas aeruginosa induced by the action of phage. J. med. Microbiol., 6, 111.

MeITERT, T. AND MeITERT, E. 1966. Utilisation combinée du sérotypage et de la lysotypie des souches de Pseudomonas aeruginosa en vue d'approfondir les investigations épidémiologiques. Arch. roum. Path. exp. Microbiol., 25, 427. 
Osman, M. A. M. 1965. Pyocine typing of Pseudomonas aeruginosa. J. clin. Path., 18, 200.

Rampling, A. 1973. Pyocins and Pseudomonas aeruginosa: applications in hospital epidemiology. Ph.D Thesis, University of Birmingham.

RAmpling, A. AND WhitBy, J. L. 1972. Preparation of phage-free pyocin extracts for use in the typing of Pseudomonas aeruginosa. J. med. Microbiol., 5, 305.

Shooter, R. A., Cooke, E. M., Gaya, H., Kumar, P., Patel, N., Parker, M. T., Thom, B. T. AND France, D. R. 1969. Food and medicaments as possible sources of hospital strains of Pseudomonas aeruginosa. Lancet, 1, 1227.

Shooter, R. A., Walker, K. A., Williams, V. R., Horgan, G. M., Parker, M. T., Asheshov, E. H. AND Bullimore, J. F. 1966. Faecal carriage of Pseudomonas aeruginosa in hospital patients. Possible spread from patient to patient. Lancet, 2, 1331.

SutTer, V. L. AND HURST, V. 1966. Sources of Pseudomonas aeruginosa infection in burns: study of wound and rectal cultures with phage typing. Ann. Surg., 163, 597.

Sutter, V. L., HuRSt, V. AND FenNell, J. 1965. A standardized system for phage typing Pseudomonas aeruginosa. Hlth Lab. Sci., 2, 7.

TAGg, J. R. AND Mushin, R. 1973. Pyocin-sensitivity testing as a means of typing Pseudomonas aeruginosa. J. med. Microbiol., 6, 559.

Tripathy, G. S. and Chadwick, P. 1971. The effect of mitomycin C on the pyocine typing patterns of hospital strains of Pseudomonas aeruginosa. Can. J. Microbiol., 17, 829.

WAHBA, A. H. 1965. Hospital infection with Pseudomonas pyocyanea: an investigation by a combined pyocine and serological typing method. $B r$. med. J., 1, 86. 